DOI: https://doi.org/10.15407/techned2018.06 $\leq \underline{022}$

\title{
ACCOUNTING OF THE BIOIMPEDANCE FEATURES AT HIGH FREQUENCY BY MODELS OF FRICKE AND COLE
}

Journal

Publisher

ISSN

Issue

Pages
Tekhnichna elektrodynamika

Institute of Electrodynamics National Academy of Science of Ukraine 1607-7970 (print), 2218-1903 (online)

No 6, 2018 (November/December)

$22-25$

\section{Authors}

\section{Sydorets, I. Pentegov, S. Rymar}

Paton Welding Institute of NAS of Ukraine,

11, K. Malevicha str., Kyiv-150, 03680, Ukraine,

e-mail: sydorvn@gmail.com

\begin{abstract}
The principles have been analyzed that were used to create models of biological tissues describing the phenomenon of bioimpedance dispersion, i.e., the laws of its dependence on frequency. The advantages and disadvantages of the Fricke and Cole models are determined, as well as the frequency ranges in which they yield results that coincide with the experiment. It is shown that the Fricke model is more promising for its adaptation in the high-frequency region, where $\beta$-dispersion is observed. In this case, it becomes possible to use it to monitor the state of biological tissue during high-frequency electrosurgical interventions. References 10, figures 2.
\end{abstract}


Key words: bioimpedance, biological tissues, dispersion, Fricke model, Cole model.

Received: 02.03 .2018

Accepted: 17.04 .2018

Published: 23.10 .2018

\section{References}

1. Paton B.E. Electric Welding of Soft Tissues in Surgery. The Paton Welding Journal. 2004. No 9. Pp. 6-10.

2. Paton B.E. Welding and Related Technologies for Medical Application. The Paton Welding Journal 2008. No11. Pp. 11-19.

3. Fricke H., Morse S. The Electric Resistance and Capacity of Blood for Frequencies between 800 and $4^{1 / 2}$ Million Cycles. The Journal of General Physiology. 1925. 9 (2), Pp. 153-157.

4. Cole, K.S., Cole, R.H. Dispersion and absorption in dielectrics. I. Alternating current characteristics. The Journal of Chemical Physics. 1941. 9(4). Pp. 341-351.

5. Grimnes S., Martinsen O.G. Bioimpedance and Bioelectricity Basics. New York: Academic, 2015. $563 \mathrm{p}$.

6. Schwan H.P. Electrical properties of tissue and cell suspensions. Advances in Biological and Medical Physics . New

York: Academic, 1957. 5. Pp. 147-209.

7. Grimnes S., Martinsen O.G. Cole Electrical Impedance Model - A Critique and an Alternative. IEEE Transactions on Biomedical Engineering. 2005. 52(6). Pp. 132-135. 
8. Krivtsun I.V., Pentegov I.V., Sydorets V.M., Rymar S.V. A Technique for Experimental Data Processing at Modeling the Dis-persion of the Biological Tissue Impedance Using the Fricke Equivalent Circuit. Electrical Engineering \& Electromechanics. 2017. No5. Pp. 27-37. DOI: https://doi.org/10.20998/2074-272X.2017.5.04

9. Grimnes S., Martinsen O.G. Alpha-Dispersion in Human Tissue. Journal of Physics:

Conference Series. 2010. 224(1). Pp. 012073. DOI: https://doi.org/10.1088/1742-6596/224/1/0 12073

10. Damez J.-L., Clerjon S., Abouelkaram S. Mesostructure Assessed by Alterning Current Spectroscopy during Meat Ageing. Proc. 51 International Congress of Meat Science and Technology . Baltimore, USA. 7-12 August, 2005. Pp. 327-330. 